\title{
Phytobiotic Utilization as Feed Additive in Feed for Pancreatic Enzyme Activity of Broiler Chicken
}

\author{
Sri Purwanti ${ }^{1}$, Zuprizal, ${ }^{2}$ Tri Yuwanta ${ }^{2}$ and Supadmo ${ }^{2}$ \\ ${ }^{1}$ Department of Animal Nutrition and Feed Science, Faculty of Animal Science, University of Hasanuddin, Jl. Perintis \\ Kemerdekaan Km. 10 Tamalanrea, 90245 Indonesia \\ 2Department of Animal Nutrition and Feed Science, Faculty of Animal Science, University of Gajah Mada, Jl. Fauna No. 3, \\ Yogyakarta, 55281 Indonesia \\ Corresponding author email: sri_p75@yahoo.com
}

\begin{abstract}
This research was conducted to evaluate the effect of turmeric water extract, garlic and combination turmeric and garlic as feed additive in broiler diet on pancreatic enzyme activity of broiler chicken. Effectivity of treatments was assessed by addition of phytobiotic (control, 015\% zinc bacitracin, 2.5\% $\mathrm{TE}, 2.0 \% \mathrm{GE}, 2.5 \% \mathrm{TGE}$ ) arranged in Completely Randomized Design with 4 replications. The variables measured were pancreatic enzyme activity(amylase enzyme activity, protease enzyme activity and lipase enzyme activity). The results showed that enzyme protein activity content of $2.5 \%$ TE supplementation was also high at $82.02 \mathrm{U} / \mathrm{ml}$, then supplemented $2.5 \% \mathrm{TGE}, 2.0 \% \mathrm{GE}$, negative control and positive control was $75.98,72.02,68.74$, and $66.57 \mathrm{U} / \mathrm{ml}$, respectively. The lipase enzyme activity whereas the negative control and a positive control differ significantly higher $(\mathrm{P}<0.05)$ to treatment with the addition of $2.5 \% \mathrm{TE}, 2.0 \% \mathrm{GE}$ and $2.5 \%$ TGE phytobiotic. The research concluded that the incorporation of $2.5 \% \mathrm{TE}, 2 \% \mathrm{GE}$ and combined $2.5 \%$ TGE as feed additive enhanced pancreatic enzyme activity.
\end{abstract}

Key words: Pancreas, Enzyme Activity, Phytobiotic, Turmeric, Garlic

\begin{abstract}
Abstrak. Penelitian ini dilakukan untuk mengevaluasi pengaruh ekstrak air kunyit, bawang putih dan kombinasi kunyit dan bawang putih sebagai aditif pakan dalam pakan broiler terhadap aktivitas enzim pankreas. Efektivitas perlakuan penambahan phytobiotic (kontrol, 015\% zinc bacitracin, 2,5\% TE, 2,0\% GE, 2,5\% TGE) menggunakan Rancangan Acak Lengkap dengan 4 ulangan. Peubah yang diukur adalah aktivitas enzim pankreas (aktivitas enzim amilase, aktivitas enzim protease dan aktivitas enzim lipase). Hasil menunjukkan bahwa aktivitas enzim protein yang mengandung 2,5\% suplemen TE tinggi yaitu 82,02 U / ml, kemudian penambahan 2,5\% TGE, 2,0 \% GE, kontrol negatif dan kontrol positif masing-masing 75,98; 72,02; 68,74; dan $66,57 \mathrm{U} / \mathrm{ml}$. Aktivitas enzim lipase, kontrol negatif dan kontrol positif berbeda secara nyata $(P<0,05)$ terhadap perlakuan dengan penambahan 2,5\% TE, 2,0\% GE dan 2,5\% TGE phytobiotic. Penelitian ini menyimpulkan bahwa penggabungan 2,5\% TE, 2\% GE dan gabungan 2,5\% TGE sebagai aditif pakan meningkatkan aktivitas enzim pankreas.
\end{abstract}

Kata kunci: Pankreas, Aktivitas Enzim, Phytobiotic, Kunyit, Bawang Putih

\section{Introduction}

Utilization of phytobiotic as natural growth promoters (NGPs) has been identified as an effective alternative to antibiotics. Phytobiotic as NGPs is highly developed as a feed additive, immunity, improve production performance and very effective to improve the health of the digestive tract (Panda et al., 2009) and stimulate livestock nutrition, anti-microbial, coccidiostatic and anti-helmintik (Panda et al., 2006). Various herbal products are found to have beneficial properties that may be useful as an alternative to antibiotic growth promoters (AGPs), which were routinely used in poultry feed. The mechanism of action of phytobiotic as AGP attributed to their ability to inhibit the growth of intestinal microflora dangerous in the gastro intestinal tract (GIT) (Hammer et al., 1999; Lopez et al., 2005) and stimulate the function of the digestive organs (Jang et al., 2004 ). Intestinal microflora has a significant effect on the host nutrients, health and performance of growth by interacting with nutrient utilization and development in the 
host's intestinal system (Hashemi and Davoodi, 2010).

Curcumin and biotransformation compound results belong to the class of polyphenolic compounds, assumedly have the same ability with membrane proteins to denature (Madigan, 2005), and to attenuate and alter membrane fluidity (Hung et al., 2008). Garlic and ginger have anti-bacterial power (Esimone et al., 2010). Widespread research on biological and pharmacological activity contained in curcumin has been done in the last decade. Anticancer effects (Marczylo et al., 2006) and its ability to induce apoptosis without showing any cytotoxic effects on normal cells is also reported (Kolev, 2005). Turmeric and ginger are herb plants that have active ingredients such as curcumin shaped phenolic compounds which can disrupt the formation of the cell membrane of some pathogenic bacteria such as Salmonella and Escherichia coli, may also increase the secretion of salivary glands, bladder, stomach, pancreas and intestines.

\section{Materials and Method}

\section{Experimental birds}

One hundred commercial unsex broiler chicks strain Cobb were used in this study, kept in cages and and randomly alloted to five treatments with four replicates of five chicks each.

\section{Experimental diet}

The experimental diet was formulated according to the standards prescribed in National Research Council (1994). Group I was offered a basal diet served as a negative control, group 2 was offered a basal diet with $0.015 \%$ Zinc bacitracin served as positive control, group 3, 4 and 5 were offered a basal diet with $0.25 \%$ turmeric extract (TE), $0.20 \%$ garlic extract (GE) and $0.25 \%$ turmeric and garlic extract (TGE), respectively, during a six-week experimental period. Feed and water were provided ad libitum to the birds throughout the experimental period. The ingredients and nutrients composition of the experimental diet are presented in Table 1. Ration was formulated every week and turmeric and garlic extract was added to the formulated ration and was properly hand-mixed to ensure homogeneous distribution of the extract.

\section{Collection of data}

At 42 days old, 20 birds ( 4 birds/treatment) were randomly selected and blended, then slaughtered following the normal procedure described by Merkcley et al. (1980) to sample the pancreas. Pancreas organ to measue activity of enzymes was stored in a container containing liquid nitrogen at $-90^{\circ} \mathrm{C}$.

\section{Sample preparation}

Evaluation of pancreatic enzyme activity through a series of enzymatic assay procedures included the stage (Routman et al., 2003; Maiorka et al., 2004; Suarni and Patong, 2007). Samples of pancreas was smoothened using mortal coupled with $0.2 \mathrm{M}$ acetate buffer $\mathrm{pH} 5$ (for every $1 \mathrm{~g}$ of sample plus $5 \mathrm{~mL}$ acetate buffer). Samples were allowed to stand for 10 minutes while occasionally shaken, then filtered using cotton. The filtrate was stored in the container effendorf then centrifuged for 20 minutes at $2000 \mathrm{rpm}$ at $5^{\circ} \mathrm{C}$. The supernatant of the pancreas was placed into a sterile container for analysis. Supernatant was frozen in liquid nitrogen until determination of enzyme activity, proceeded with titration to evaluate some pancreatic enzyme activity of the enzyme pancreatic lipase (Lindfield et al., 1984), the protease enzyme was conducted by Malathi and Chakraborty (1991) as modified by Kwan et al. (1983), the enzyme amylase was measured as described by Bernfeld (1955) cit. Soeka and Eddy (1993), and protein enzymes.

\section{Statistical analysis}

Data for pancreatic enzyme activity were subjected to an analysis of variance. The treatments means with significant differences at $\mathrm{P}<0.05$ were compared using orthogonal contrast procedure (Steel and Torrie, 1995). 
Table 1: Ingredients and nutrient composition of broilers ration

\begin{tabular}{|c|c|c|c|c|c|}
\hline \multirow{3}{*}{ Ingredients } & \multicolumn{5}{|c|}{ Percentage (\%) } \\
\hline & Negative & Positive & $2.5 \% \mathrm{TE}$ & $2.0 \%$ & $2.5 \%$ \\
\hline & control & control & & GE & TGE \\
\hline Corn & 63.00 & 63.00 & 63.00 & 63.00 & 63.00 \\
\hline Meat and bone meal & 4.50 & 4.50 & 4.50 & 4.50 & 4.50 \\
\hline Poultry meat meal & 6.00 & 6.00 & 6.00 & 6.00 & 6.00 \\
\hline Oil & 2.00 & 2.00 & 2.00 & 2.00 & 2.00 \\
\hline Soybean & 20.00 & 20.00 & 20.00 & 20.00 & 20.00 \\
\hline $\mathrm{CaCO}_{3}$ & 1.00 & 1.00 & 1.00 & 1.00 & 1.00 \\
\hline DCP & 0.30 & 0.30 & 0.30 & 0.30 & 0.30 \\
\hline Vitamins and minerals ${ }^{*}$ & 0.25 & 0.25 & 0.25 & 0.25 & 0.25 \\
\hline Salt & 0.25 & 0.25 & 0.25 & 0.25 & 0.25 \\
\hline L-Lysin- $\mathrm{HCl}$ & 0.10 & 0.10 & 0.10 & 0.10 & 0.10 \\
\hline DL-Methionin & 0.10 & 0.10 & 0.10 & 0.10 & 0.10 \\
\hline Zinc Bacitracin & 0.00 & 0.015 & 0.00 & 0.00 & 0.00 \\
\hline $\mathrm{TE}$ & 0.00 & 0.00 & 2.50 & 0.00 & 0.00 \\
\hline GE & 0.00 & 0.00 & 0.00 & 2.00 & 0.00 \\
\hline TGE & 0.00 & 0.00 & 0.00 & 0.00 & 2.50 \\
\hline Filler & 2.50 & 2.485 & 0.00 & 0.50 & 0.00 \\
\hline Total & 100 & 100 & 100 & 100 & 100 \\
\hline \multicolumn{6}{|l|}{ Calculated composition } \\
\hline Metabolizable energy, kcal/kg & & & & & 3003.09 \\
\hline Crude protein, \% & & & & & 20.03 \\
\hline Crude fibre, $\%$ & & & & & 3.00 \\
\hline Ether extract, \% & & & & & 3.78 \\
\hline Calcium, \% & & & & & 1.11 \\
\hline $\mathrm{P}$ - available, \% & & & & & 0.56 \\
\hline L-Lysin-HCl, \% & & & & & 1.06 \\
\hline DL-Methionin, \% & & & & & 0.402 \\
\hline
\end{tabular}

\section{Results and Discussion}

Pancreas is one organ that has an important role in food digestion. Pancreas produces fluid that is channeled into the duodenum at the pylorus valve place. According to some studies, phytogenic can stimulate the production of digestive enzymes such as lipase, amylase, or carbohydrates, so it has a beneficial effect on the utilization of nutrients (Ramakhrisna Rao et al., 2003; William and Losa, 2001). Pancreatic enzyme activity including the activity of the enzyme amylase, lipase and protease enzymes is presented in Table 2.

\section{Amylase enzyme activity}

As shown in Table 2, it was proven that phytobiotic supplementation in broiler chickens through ration affected pancreatic amylase enzyme activity at the age of $\mathbf{4 2}$ days. Statistical analysis showed significant difference $(P<0.05)$ between treatment groups supplemented with 2.5\% TE, 2.0\% GE and 2.5\% TGE and that without phytobiotic supplement. Phytobiotic 
Table 2. Pancreatic enzyme activity of broilers with the addition of TE, GE and TGE $(n=15)$

\begin{tabular}{|c|c|c|c|c|c|c|c|}
\hline \multirow{2}{*}{ Variables } & \multicolumn{5}{|c|}{ Treatments } & \multirow[b]{2}{*}{ SEM } & \multirow[b]{2}{*}{ P-value } \\
\hline & $\begin{array}{l}\text { Negatif } \\
\text { control }\end{array}$ & $\begin{array}{l}\text { Positif } \\
\text { control }\end{array}$ & $2.5 \% \mathrm{TE}$ & $2.0 \% \mathrm{GE}$ & $2.5 \% \mathrm{TGE}$ & & \\
\hline $\begin{array}{l}\text { Amylase enzyme activity } \\
(\mathrm{SC} / \mathrm{ml})\end{array}$ & $94.62^{a}$ & $95.83^{a}$ & $97.13^{b}$ & $97.20^{\mathrm{b}}$ & $96.59^{b}$ & 0.38 & 0.16 \\
\hline $\begin{array}{l}\text { Protease enzyme } \\
\text { activity }(\mathrm{U} / \mathrm{ml})^{\mathrm{ns}}\end{array}$ & 462.46 & 551.23 & 613.69 & 536.56 & 525.75 & 20.19 & 0.21 \\
\hline $\begin{array}{l}\text { Lipase enzyme activity } \\
(\mathrm{U} / \mathrm{ml})\end{array}$ & $5.63^{a}$ & $4.19^{a}$ & $3.66^{b}$ & $1.86^{b}$ & $1.73^{b}$ & 0.54 & 0.08 \\
\hline Protein enzim $(\mathrm{U} / \mathrm{ml})^{\mathrm{ns}}$ & 68.74 & 66.57 & 82.02 & 72.02 & 75.98 & 4.04 & 0.69 \\
\hline
\end{tabular}

single supplementation has amylase enzyme activity similar to phytobiotic combined. Further contrast to the orthogonal contrast test 4 showed no significant differences $(P>0.05)$ on the activity of the amylase enzyme, but significant difference between the control lower $(P<0.05)$ to the treatments supplemented phytobiotic. No significant differences $(P<0.05)$ were found between the positive control and negative control treatment. Supplementation of 2.5\% TE, 2.0\% GE and 2.5\% TGE was 97.13 $\mathrm{U} / \mathrm{ml}, 97.20 \mathrm{U} / \mathrm{ml}$ and $96.59 \mathrm{U} / \mathrm{ml}$, respectively, while the activity of the amylase enzyme treatment not supplemented with phytobiotic i.e. negative control and positive control was $94.62 \mathrm{U} / \mathrm{ml}$ and $95.83 \mathrm{U} / \mathrm{ml}$, respectively.

Platel and Srinivasan (2004) stated that curcumin supplementation of $0.5 \%$ given continuously in the diet of mice is able to stimulate increase in amylase activity by $96 \%$, while garlic supplementation decrease $0.5 \%$ to $5 \%$. Researchers reported that the activity of pancreatic lipase and amylase did not increase with the addition of $100 \mathrm{mg} / \mathrm{kg}$ of mixture containing carvacrol, cinnamaldehyde and capsaicin in broilers despite the improvement of feed additives provide good feed conversion (Jamroz et al., 2005).

Amylase enzyme activity with bacitracin zinc supplementation $0.015 \%$ of the results of this study, although not significantly different to the negative control but has the amylase enzyme activity is quite high. According to the research Engberd et al. (2000) that zinc bacitracin 20 $\mathrm{mg} / \mathrm{kg}$ can stimulate the activity of amylase, lipase and chymotrypsin in pancreatic duct, and the addition of Salinomycin $60 \mathrm{mg} / \mathrm{kg}$ reduces the activity of the enzyme amylase and lipase.

\section{Protease enzyme activity}

Statistical protease enzyme activity as indicated in Table 2 did not show any significant difference $(P>0.05)$ with all treatments, either treatment with or without phytobiotic supplementation. Protease enzyme activity in the treatment of negative control, positive control, supplementation of $2.5 \% \mathrm{TE}, 2.0 \% \mathrm{GE}$ and $2.5 \%$ TGE was 462.46; 551.23; 613.69; 536.56 and $525.75 \mathrm{U} / \mathrm{ml} / \mathrm{min}$, respectively. No visible significance was observed but numerically treatment with $2.5 \%$ TE phytobiotic supplementation showed higher protease enzyme activity compared to the other treatments, while supplementation of Zinc bacitracin was still higher than the supplementation $2.0 \%$ GE, $2.5 \%$ TGE and negative control.

High protein level is not correlated with the highest protease content. The precipitated protein not only contains protease protein but also other non-enzyme proteins or even measurable when analyzing the protein 
content. Results showed the enzyme protein content of $2.5 \%$ TE supplementation was also high at $82.02 \mathrm{U} / \mathrm{ml}$, while the supplemented 2.5\% TGE, 2.0\% GE, negative control and positive control was $75.98 ; 72.02 ; 68.74$; and $66.57 \mathrm{U} / \mathrm{ml}$, respectively.

Khan et al. (2012) reported that the active substance of curcumin found in turmeric may increase the activity of lipase, amylase, trypsin and chymotrypsin in broiler. Diet containing curcumin can increase the secretion of digestive enzymes and digestibility of nutrients and energy. Several studies in rats with supplementation of turmeric can increase the flow and secretion of bile acids (Platel and Srinivasan, 2001) which stimulates the secretion of digestive enzymes in pancreas such as amylase, lipase protease and chymotrypsin (Platel and Srinivasan, 2000).

\section{Lipase enzyme activity}

The statistically significant difference $(P<0.05)$ of extract phytobiotic on the parameters of pancreatic lipase activity is shown in Table 1 . The test results on the contrasts orthogonal, contrast test 4 showed that the negative control and a positive control differ significantly $(P<0.05)$ to treatment with the addition of $2.5 \% \mathrm{TE}, 2.0 \% \mathrm{GE}$ and $2.5 \% \mathrm{TGE}$ phytobiotic. Treatment with the addition of either single or combined phytobiotic showed no significant differences $(P>0.05)$, also between negative and positive control treatment. Lipase activity with the treatment of the negative control, positive control, 2.5\% TE, 2.0\% GE and 2.5\% TGE respectively 5.63; 4.19; $3.86 ; 1.86 ; 1.73 \mathrm{U} / \mathrm{ml}$.

Lipase activity in this study with additional treatment 2.5\% TE, 2.0\% GE and 2.5\% TGE phytobiotic was lower than control. In this study using TE, Ge and TGE known as a phytochemical test showed that TE contained metabolites such as curcumin, saponins, tannins, flavonoids, while GE contained flavonoids, saponins, phenols, also tannin. It was expected that these compounds could inhibit the activity of lipase enzyme. Saponins on garlic and turmeric extracted either by water is polar.

Another study also reported active compounds that have the potential to inhibit the activity of the pancreatic lipase is a saponin contained in plant Theasinensis (Han et al., 2001) and Platycodi radix (Xu et al., 2005), Panax japonicas (Han et al., 2005), Kochiascoparia (Han et al., 2006) and falvonoid contained in the leaves of Dutch identity (Darusman et al., 2001). Pancreatic lipase activity increases, it will increase the absorption of monoglycerides and fatty acids that affect obesity (Joshita et al., 2000). This is what will lead to the accumulation of fat in the body. Therefore, it needs to inhibit the absorption of fat through inhibition of pancreatic lipase activity so that fat accumulation is prevented. Pancreatic lipase is an enzyme found in body, which especially plays a role in lipid decomposition to absorb fatty acids (Shin et al., 2003).

\section{Conclusions}

The research concluded that the incorporation of $2.5 \% \mathrm{TE}, 2 \% \mathrm{GE}$ and combined $2.5 \%$ TGE as feed additive enhanced pancreatic enzyme activity (Amylase, protease, lipase and protein enzyme activity).

\section{References}

Darusman LK, E Rohaeti dan Sulistiyani. 2001. Evaluation of flavonoid compounds derived from bangle plant as fat. Kajian senyawa golongan flavonoid asal tanaman bangle sebagai senyawa peluruh lemak melalui aktivitas lipase. Pusat Studi Biofarmaka Lembaga Penelitian, IPB, Bogor.

Engberg RM, MS Hedeman, TD Leser, BB Jensen. 2000. Effect of Zinc Bacitracin and Salinomycin on intestinal microflora and 
performance of broilers. Poult. Sci. 79:1311-1319.

Esimone CO, FBC Okoye, DC Odomegwu, CS Nworu, PP Oleghe, and PW Ejogha. 2010. In vitro antimicrobial evaluation of lozenges containing extract of garlic and ginger. Int. J. of Health Res. 3(2):105-110.

Kwan KKH, S Nakai, BJ Skura. 1983. Comparison of four methods for determining protease activity in milk. J. Food Sci. 48(5):14181421.

Linfield WM, DJ O'Brien, S Serota and RA Barauskas. 1984. Lipid-lipase interactions. I. Fat splitting with lipase from Candida rugosa. J. Am. Oil Chem Soc. 61:1067-1071.

Lopez P, C Sanchez, R Batlle, C Nerin. 2005. Solid-and vapor-phase antimicrobial activities of six essential oils: Susceptibility of selected foodborne bacterial and fungal strains. J. Agr. Food Chem. 53:6939-6946.

Hammer KA, CF Carson and TV Riley. 1999. Antimicrobial activity of essential oils and other plant extracts. J. App. Microbiol. 86:985-990.

Han LK, Y Kimura, M Kawashima, T Takaku, T Taniyama, $\mathrm{T}$ Hayashi, $\mathrm{YN}$ Zheng and $\mathrm{H}$ Okuda, 2001. Anti-obesity effects in rodents of dietary teasaponin, a lipase inhibitor. Int. J. Obesity. 25:1459-1464.

Han LK, NY Zheng, M Yoshikawa, H Okuda, Y Kimura. 2005. Anti-obesity effects of chikusetsu saponins isolated from Panaxjaponicus rhizomes. BioMed Central. 5:1-10.

Han LK, R Nose, W Li, XJ Gong, YN Zheng, M Yoshikawa, K Koike, T ikaido, H Okuda and Y Kimura. 2006. Reduction of fat storage in mice fed a high-fat diet long term by treatment with saponins prepared from Kochiascoparia fruit. Phythoter. Res. 20: $877-882$.

Hashemi, SR and H Davoodi. 2010. Phytogenics as new class of feed additive in poultry industry. J. Anim. Vet. Adv. 9(17):22952304.

Hung WC, FY Chen, CC Lee, Y Sun, HW Huang. 2008. Membrane-thinning effect of curcumin. J. Biophys. 94:4331-4338.

Jamroz D, A Wiliczkiewicz, T Wertelecki, J Orda and J Skorupinska. 2005. Use of active substances of plant origin in chicken diets base om maize and locally grown cereals. Brit. Poult. Sci. 46:485-493.

Jang IS, YH Ko, HY Yang, JS Ha, JY Kim, SY Kang, DH Yoo, DS Nam, DH Kim and CY Lee. 2004. Influence of essensial oil components on growth performances and the functional activity of the pancreas and small intestine in broiler chickens. Asian-australas. J. Anim. Sci. 17:394-400.

Joshita D, Azizahwati, Wahyuditomo, 2000. Pengaruh daun jati belanda terhadap kerja enzim lipase secara in vitro. Warta TumbuhanObat Indonesia 6(2):16-22.

Khan, RU, S Naz, M Javdani, Z Nikousefat, M Selvaggi, V Tufarelli, and V Laudadio. 2012. The use of Turmeric (Curcuma longa) in poultry feed. World's Poult. Sci. J. 68:97-103.

Kolev TM. 2005. DFT and experimental studies of the structure and vibrational spectra of curcumin. International Journal of Quantum Chemistry. 102(6):1069-1079.

Madigan M. 2005. Brock Biology of Microorganisms. London. Prentice Hall.

Maiorka A, AVF da Silva and E Santin. 2004. Broiler breeder age and dietary energy level on performance and pancreas lipase and trypsin activities of 7-days old chicks. Int. J. Poult. Sci. 3(3):234-237.

Malathi S and R Chakraborty. 1991. Production of alkaline protease by a New Aspergillusflavus isolate under solid substrate fermentation conditions for use as a depilation agent. Appl. Environ. Microbiol. 57(3):712-716. 
Marczylo TH, RD Verschoyle, DN Cooke, P Morazzoni, WP Steward and AJ Gescher. 2006. Comparison of systemic availability of curcumin with that of curcumin formulated with phosphatidylcholine. Cancer Chemother Pharmacol 60:17-177.

Merkley JW, BT Weinland, GW Malone and GW Chaloupka. 1980. Evaluation of five commercial broiler crosses. 2. Eviscerated yield and component parts. Poult. Sci., 59: 1755-1760.

National Research Council (NRC). 1994. Nutrient Requirements of Poultry. Ed Rev ke9. Washington DC: Academy Pr.

Panda A, SR Rao and M Raju, M., 2006. Natural growth promoters have potential in poultry feeding systems. Feed tech. 10(8):23-35.

Panda A, SR Rao and M Raju, M., 2009. Phytobiotics, a natural growth promoter. Poultry International. pp: $10-11$.

Platel K and K Srinivasan. 2004. Digestive stimulant action of spices: A myth or reality? The Indian J. Med. Res.119:167-179.

Platel K and K Srinivasan 2001. Studies on the influence of dietary spices on food transit time in experimental rats. Nutr. Res. 21: 1309-1314.

Platel, K, and K Srinivasan. 2000. Influence of dietary spices and their active principles on pancreatic digestive enzymes in albino rats. Food/Nahrung. 44:42-46.

Ramakrishna R, K Platel and K Srinivasan. 2003. In vitro influence of spices and spice-active principles on digestive enzymes of rat pancreas small intestine. Nahrung/Food. 47: 408-412.

Routman KS, L Yoshida, AC Frizzas de Lima, M Maccari and JM Pizauro Jr. 2003. Intestinal and pancreas enzyme activity of broilers exposed to thermal stress. Braz. J. Poult. Sci. 5(1):23-27.

Shin JE, MJ Han and DH Kim. 2003. 3Methylethergalangin isolated from Alpiniaofficinarum inhibits pancreatic lipase. Biol. Pharm Bull. 26(6):854-857.

Soeka, Y Sudaryati dan E Djajasukma. 1993. Pengaruh penambahan sumber-sumber nitrogen terhadap aktivitas enzim alpha amilase Aspergillus niger dalam media campuran onggok dan dedak. Prosiding Seminar Hasil Litbang SDH.

Steel RGD and JH Torrie. 1995. Prinsip dan Prosedur Statistika. Suatu Pendekatan Biometrik. Ed ke-2. Ir. Bambang Sumantri, penerjemah. GM: Penerbit PT Gramedia Pustaka Utama. Terjemahan dari : Principles and Procedures of Statistics.

Suarni and R Patong. 2007. Potency of Mung bean sprout as enzyme source ( $\alpha$-amilase). Indo. J. Chem. 7(3):332-336.

$\mathrm{Xu}, \mathrm{BJ}$, LK Han, YN Zheng, JH Lee and CK Sung. 2005. In vitro inhibitory effect of triterpenoidalsaponins from Platycodi radix on pancreatic lipase. Arch. Pharm. Res. 28(2):180-185.

Williams $P$ and $R$ Losa. 2001. The use of essential oils and their compound in poultry nutrition. World's Poult. Sci. J. 17:14-15. 